\title{
Analisis inflasi di lihat dari permintaan dan penawaran di Indonesia Tahun 2000-2018
}

\author{
Desy Martauli*; Amri Amir; Candra Mustika
}

Program Studi Ekonomi Pembangunan, Fak. Ekonomi dan Bisnis, Universitas Jambi

*E-mail korespondensi: martaulidesy@gmail.com

\begin{abstract}
This study aims to determine the analysis of inflation in terms of demand and supply in Indonesia in 2000-2018, the variables studied are the exchange rate, loan interest rates, world oil prices, public consumption. The type of time series data with the analytical method used in this study is using simple linear regression analysis and multiple linear regression (OLS) methods. The results of the trend of each variable inflation, exchange rate, interest rates on loans, world oil prices and public consumption fluctuate and have a tendency to increase with average inflation of $2.71 \%$, the exchange rate of $R p .14,143$, the loan interest rate of $12.15 \%$, the price of world oil is $91.67 \%$ and Indonesian people's consumption is 6,850,384 billion rupiah. The results of simple linear regression and multiple linear regression are shown through the simultaneous test $(F$ test) that the exchange rate, loan interest rate, world oil price, and public consumption have a positive and significant effect on inflation in Indonesia. The results of the partial test (t-test) show that the loan interest rate and world oil prices have a positive and significant effect on inflation in Indonesia and public consumption has a negative and significant effect on inflation in Indonesia, while the exchange rate has a positive and significant effect on inflation in Indonesia.
\end{abstract}

Keywords: Inflation, Exchange rate, Loan interest rate, World oil price, Community consumption

\begin{abstract}
Abstrak
Penelitian ini bertujuan untuk mengetahui analisis inflasi di lihat dari permintaan dan penawaran di Indonesia Tahun 2000-2018, variabel yang diteliti yaitu kurs, tingkat bunga pinjaman, harga minyak dunia, konsumsi masyarakat. Jenis data time series dengan metode analisis yang digunakan dalam penelitian ini adalah menggunakan analisis regresi linier sederhana dan regresi linier berganda metode (OLS). Hasil trend masing-masing variabel inflasi, kurs, tingkat bunga pinjaman, harga minyak dunia dan konsumsi masyrakat berfluktuasi dan memiliki kecendrungan meningkat dengan ratarata inflasi sebesar 2,71\%, kurs Rp.14.143, tingkat bunga pinjaman 12,15\%, harga minyak dunia 91,67\% dan konsumsi masyarakat Indonesia sebesar 6.850 .384 miliyar rupiah. Hasil regresi linier sederhana dan regresi linier berganda yang ditunjukkan melalui uji simultan (uji F) bahwa kurs, tingkat bunga pinjaman, harga minyak dunia dan konsumsi masyarakat berpengaruh positif dan signifikan terhadap inflasi di Indonesia. Hasil uji parsial (uji t) menunjukkan bahwa tingkat bunga pinjaman dan harga minyak dunia berpengaruh positif dan signifikan terhadap inflasi di Indonesia dan konsumsi masyarakat berpengaruh negatif dan signifikan terhadap inflasi di indonesia sementara kurs dan berpengaruh positif dan tidak signifikan signifikan terhadap inflasi di Indonesia.
\end{abstract}

Kata kunci: Inflasi, Kurs, Tingkat bunga pinjaman, Harga minyak dunia, Konsumsi masyarakat 


\section{PENDAHULUAN}

Pertumbuhan dan kestabilan ekonomi merupakan pembangunan nasional dalam rangka meningkatkan kesejahteraan masyarakat yang merata. Dengan pertumbuhan yang stabil dan maksimal, negara dapat melanjutkan pembangunan dan memberikan pelayanan yang baik bagi rakyatnya. Oleh karena itu, pertumbuhan dan kestabilan ekonomi merupakan dua hal yang perlu diupayakan sebaik mungkin. Salah satu sumber ketidakstabilan ekonomi yang utama dan dapat mengganggu pertumbuhan ekonomi adalah terjadinya kenaikan secara umum dan terus menerus, atau lebih dikenal dengan sebutan inflasi.

Inflasi adalah sumber utama ketidakmerataan ekonomi, sosial dalam jangka pendek maupun jangka panjang dan merupakan salah satu peristiwa moneter yang terjadi di berbagai negara, baik negara maju maupun negara sedang berkembang. Seperti yang dikatakan Milton Friedman bahwa inflasi terjadi dimana saja, kapan saja dan selalu menjadi fenomena moneter (Mankiw, 2006:199).

Secara umum pendekatan inflasi bisa dilihat dari (Demand Pull Inflation), (Cost Push Inflation). Demand Pull Inflation disebabkan karena pengaruh dari konsumsi masyarakat serta jumlah uang beredar, jumlah atau laju pertumbuhan permintaan agregat lebih tinggi daripada jumlah atau laju pertumbuhan penawaran agregat. Cosh Push Inflation disebabkan oleh biaya produksi dan impor yang tinggi sehingga pada gilirannya akan menyebabkan penawaran agregat akan rendah, biaya produksi sendiri bisa diartikan dngan harga minyak dunia, suku bunga dan kurs.

Menurut Boediono (1996: 76), Suku Bunga adalah harga yang harus dibayar apabila terjadi pertukaran antara satu rupiah sekarang dan satu rupiah nanti. Adanya kenaikan suku bunga yang tidak wajar akan menyulitkan dunia usaha untuk membayar beban bunga dan kewajiban, karena suku bunga yang tinggi akan menambah beban bagi perusahaan sehingga secara langsung akan mengurangi profit perusahaan.

Kurs juga memegang peranan penting dalam perdagangan antar negara. Perubahan nilai tukar akan berdampak pada aktivitas perdagangan maupun aktivitas ekonomi suatu negara. Kurs atau nilai tukar adalah harga sebuah mata uang dari suatu negara, yang diukur atau dinyatakan dalam mata uang lainnya (Krugman, 2005). Saat ini Indonesia menganut system nilai tukar mengambang penuh/bebas (Freely Floting System). System nilai tukar mengambang penuh/bebas merupakan system dimana posisi nilai tukar rupiah terhadap mata uang asing ditentukan oleh mekanisme pasar.

Konsumsi masyarakat dipengaruhi oleh banyak faktor, diantaranya faktor pendapatan kekayaan, tingkat suku bunga dan inflasi. Hal ini didukung oleh teori yang telah dikembangkan oleh para ahli ekonomi. Menurut Keynes yang dikutip dalam Mankiw (2003) menyatakan bahwa pengeluaran konsumsi masyarakat tergantung (berbanding lurus) dengan tingkat pendapatannya.

Harga bahan bakar minyak yang murah jelas menimbulkan resiko dan biaya yang lebih besar bagi negara. Kebijakan untuk memberikan subsidi BBM telah menyebabkan tekanan fiskal yang besar. Dengan terus meningkatnya harga minyak dipasaran internasional dan terus meningkatnya jumlah impor bahan bakar minyak yang dilakukan oleh Indonesia, pemerintah mengambil keputusan untuk mengurangi jumlah subsidi atas bahan bakar minyak dengan menaikan harga bahan bakar minyak di dalam negeri (Suryadi,2007:22).

Berdasarkan uraian di atas, maka penulis tertarik untuk mengangkat permasalah tersebut untuk dilakukan penelitian dengan judul "Analisis inflasi di lihat dari permintaan dan penawaran di Indonesia Tahun 2000-2018".

\section{METODE}

Jenis data yang digunakan dalam penelitian ini adalah Data Sekunder, berupa data time series kurun waktu 2000-2018 yang berasal dari survey yang telah diproses oleh 
Badan Pusat Statistik Provinsi Jambi. Data penelitian bersumber dari Badan Pusat statistik Indonesia, Bank Indonesia, Kemenrian Perdagangan, OPEC, Referensi Jurnal, Makalah, dan lain sebagainya. Metode analisis yang digunakan yaitu analisis deskriptif dan analisis kuantitatif.

Melihat trend inflasi, kurs, tingkat bunga pinjaman dan harga minyak dunia digunakan dengan rumus:

$$
\mathbf{Y}=\mathbf{a}+\mathbf{b} \mathbf{T}
$$

Dimana:

$\mathrm{Y}=$ Nilai trend atau variabel yang akan diramalkan

a = Bilangan konstan

$\mathrm{b}=$ Slope atau koefisien garis trend

$\mathrm{T}=$ Tahun yang akan diramalkan

Sementara, untuk melihat pengaruh kurs, tingkat bunga pinjaman, harga minyak dunia dan konsumsi masyarakat terhadap inflasi di Indonesia digunakan dengan dua model regresi yaitu regresi linier sederhana dan regresi linier berganda dengan formula sebagai berikut:

$$
\mathrm{INF}=\boldsymbol{\beta}_{0}+\boldsymbol{\beta}_{1} \mathrm{KM}+\varepsilon
$$

Dimana :

$\mathrm{INF}=$ Inflasi

$\mathrm{KM}=$ Konsumsi masyarakat

$\beta_{0} \quad=$ Konstanta

$\beta_{1} \quad=$ Koefisien dari variabel $\mathrm{KM}$

$\varepsilon \quad=$ Error term

\section{Model Regresi linier berganda dari sisi penawaran}

$$
\mathrm{INF}=\beta_{0}+\beta_{1} \mathrm{ER}+\beta_{2} \mathrm{TBP}+\beta_{3} \mathrm{HMD}+\varepsilon
$$

Dimana :

$\mathrm{INF}=$ Inflasi

$\mathrm{ER}=\operatorname{Kurs}($ Exchange Rate)

TBP $=$ Tingkat bunga pinjaman

$\mathrm{HMD}=$ Harga minyak dunia

$\beta_{0} \quad=$ Konstanta

$\beta_{1} \quad=$ Koefisien dari variabel ER

$\beta_{2} \quad=$ Koefisien dari variabel TBP

$\beta_{3} \quad=$ Koefisien dari variabel HMD

$\varepsilon \quad=$ Error term

\section{HASIL DAN PEMBAHASAN}

Trend kurs, tingkat bunga pinjaman, harga minyak dunia dan konsumsi masyarakat terhadap inflasi di Indonesia.

Berdasarkan table dibawah ini bahwa trend inflasi, kurs, tingkat bunga pinjaman, harga minyak dunia dan konsumsi masyarakat Indonesia dari tahun 2019-2025 memiliki kecendrungan meningkat. 
Tabel 1. Trend inflasi Indonesia Tahun 2019-2025

\begin{tabular}{cc}
\hline Tahun & Trend inflasi (\%) \\
\hline 2019 & 2,37 \\
2020 & 2,48 \\
2021 & 2,60 \\
2022 & 2,71 \\
2023 & 2,83 \\
2024 & 2,94 \\
2025 & 3,06 \\
\hline Rata-rata & $\mathbf{2 , 7 1}$
\end{tabular}

Sumber: Bank Indonesia 2018 (diolah)

Trend inflasi di indonsia dari tahun 2019-2025 dengan rata-rata sebesar 2,71 persen. Inflasi, kenaikan harga barang secara umum, yang tinggi akan menjadi beban oleh banyak pihak. Dengan inflasi, maka daya beli suatu mata uang menjadi lebih rendah atau menurun. Dengan menurunnya daya beli mata uang, maka kemampuan masyarakat berpendapatan tetap dalam membeli barang dan jasa kebutuhan sehari-hari akan menjadi semakin rendah. Dalam suatu perekonomian modern, tingkat harga merupakan indikator atau sinyal yang sangat penting dalam menjaga keseimbangan alokasi sumber daya ekonomi dalam suatu negara

Tabel 2. Trend kurs Indonesia Tahun 2019 - 2025

\begin{tabular}{cc}
\hline Tahun & Trend kurs (Rp) \\
\hline 2019 & 13.363 \\
2020 & 13.623 \\
2021 & 13.883 \\
2022 & 14.143 \\
2023 & 14.403 \\
2024 & 14.663 \\
2025 & 14.923 \\
\hline Rata-rata & $\mathbf{1 4 . 1 4 3}$
\end{tabular}

Sumber: Kementrian perdagangan 2018 (diolah)

Trend kurs di Indonesia dari tahun 2019-2025 dengan rata-rata sebesar Rp.14.143. Penyebab dari adanya peningkatan terhadap kurs adalah karena dipengaruhi oleh faktor politik dan pisikologi, nilai tukar rupiah terhadap dolar Amerika Serikat yang mulai stabil. Adapun penyebab dari adanya penurunan terhadap kurs karena meningkatnya suku bunga SBI dan respon terhadap naiknya tingkat bunga deposito sehingga pertumbuhan uang beredar terbilang lambat, karena pernah terjadi krisis global yang melanda Amerika Serikat sehingga berdampak terhadap Indonesia. Pada ekonomi internasional telah mengalami beberapa perkembangan yang sangat pesat.

Trend Tingkat bunga pinjaman di Indonesia dari tahun 2019-2025 dengan ratarata sebesar 12,15 pesen. Sampai saat ini suku bunga kredit masih dikeluhkan banyak pihak karena tak kunjung turun. Padahal BI Rate hampirsetahun ini masih bertengker di angka 6,50\%, namun suku bunga kredit masih saja berada di level dua digit. Suku bunga kredit modal kerja per bulan April 2010 masih di level 13,42\%, kredit investasi di level 12,62\% dan kredit konsumsi di level 15,34\%. Beberapa faktor yang 
mempengaruhi tingginya tingkat suku bunga kredit adalah pertama, laju permintaan kredit yang lebih besar dibandingkan pertumbuhan sumber dananya.

Tabel 3. Trend tingkat bunga pinjaman Tahun 2019 - 2025

\begin{tabular}{cc}
\hline Tahun & Trend tingkat bunga pinjaman $(\boldsymbol{\%})$ \\
\hline 2019 & 13,29 \\
2020 & 12,91 \\
2021 & 12,53 \\
2022 & 12,15 \\
2023 & 11,77 \\
2024 & 11,39 \\
2025 & 11,01 \\
\hline Rata-rata & $\mathbf{1 2 , 1 5}$
\end{tabular}

Sumber: Badan pusat statistik 2018 (diolah)

Kedua, ekspetasi para investor yang tinggi terhadap imbal hasil perbankan Nasional yang tertuang dalam Rencana Kerja Anggaran Perusahaan (RKAP). Ketiga, risk premium masin tinggi, keempat, adanya pergeseran portofolio kredit ke arah kredit UMKM semakin deras mengingat kredit UMKM sangat tebal marginnya, kelima, komposisi kredit pada aset perbankan dibebrapa negara tidak dominan menunjukkan bahwa bank-bank diluar negeri menopang biaya overhead-nya dengan pendapatan non bunga yang berbasis Fee Based Income (FBI).

Tabel 4. Trend harga minyak dunia Tahun 2019 - 2025

\begin{tabular}{cc}
\hline Tahun & Trend harga minyak dunia ( /barel) \\
\hline 2019 & 85,56 \\
2020 & 87,60 \\
2021 & 89,64 \\
2022 & 91,68 \\
2023 & 93,72 \\
2024 & 95,76 \\
2025 & 97,78 \\
\hline Rata-rata & $\mathbf{9 1 , 6 7}$
\end{tabular}

Sumber: OPEC 2018 (data diolah)

Trend Harga minyak dunia di Indonesia dari tahun 2019-2025 dengan rata-rata sebesar 91,67 pesen. Minyak dan trend harganya memberikan pengaruh yang sangat vital pada semua aktivitas makroekonomi, karena minyak merupakan salah satu energi utama yang digunakan baik langsung maupun tidak langsung dalam memperoleh barang dan jasa. Minyak menjadi sumber energi teratas pengunaanya untuk menopang proses produksi dibandingkan dengan sumber energi lainnya, sehingga fluktuasi harga minyak sangat sensitif dengan kondisi perekonomian atau pertumbuhan ekonomi di setiap negara. Dan tidak ada satu negara pun yang tidak tergantung pada minyak dan mampu secara serta merta menurunkan konsumsinya akibat kenaikan tak terkecuali di Indonesia.

Trend Konsumsi masyarakat di Indonesia dari tahun 2019-2025 dengan rata-rata sebesar 6.850.384 Miliyar Rupiah. Salah satu komponen penting untuk menilai perkembagan tingkat kesejahteraan ekonomi penduduk adalah pola pengeluaran 
konsumsi masyarakat. Pengeluaran konsumsi masyarakat merupakan pembelanjaan yang dilakukan oleh rumah tangga terhadap barang-barang akhir dan jasa-jasa dengan tujuan untuk memenuhi kebutuhan seperti makanan, pakaian, dan barang-barang kebutuhan lainnya serta berbagai jenis pelayanan.

Tabel 5. Trend konsumsi masyarakat Indonesia Tahun 2019-2025

\begin{tabular}{cc}
\hline Tahun & $\begin{array}{c}\text { Trend konsumsi masyarakat Indonesia } \\
\text { (Miliyar Rupiah) }\end{array}$ \\
\hline 2019 & 5.953 .061 \\
2020 & 6.252 .169 \\
2021 & 6.551 .276 \\
2022 & 6.850 .384 \\
2023 & 7.149 .492 \\
2024 & 7.448 .600 \\
2025 & 7.747 .708 \\
\hline Rata-rata & $\mathbf{6 . 8 5 0 . 3 8 4}$ \\
\hline
\end{tabular}

Sumber: Badan pusat statistik 2018 (diolah)

Konsumsi rumah tangga dalam perekonomian terjadi karena adanya pendapatan yang diperoleh rumah tangga yang berasal dari penggunaan faktor-faktor produksi yang dimilikinya dibedakan menjadi 4 golongan yaitu tanah, tenaga kerja, modal dan keahlian kewirausahaan. Apabila faktor-faktor produksi tersebut digunakan oleh sektor perusahaan dan pemerintah maka akan mewujudkan aliran pendapatan ke sektor rumah tangga berupa gaji dan upah, sewa, bunga dan keuntungan.

\section{Analisis inflasi di lihat dari permintaan dan penawaran}

\section{Analisis regresi}

Hasil perhitungan regresi dalam penelitian ini dapat di lihat pada tabel 6, dengan menggunakan regresi linier sederhana dan regresi linier berganda dengan tingkat signifikan sebesar $\alpha=5 \%$ yaitu sebagai berikut:

Tabel 6. Hasil koefisien regresi dari sisi permintaan

\begin{tabular}{ccccccc}
\hline Variabel & Coefisien & t-hitung & Prob t-hit & F-hitung & Prop F-hit & R $^{\mathbf{2}}$ \\
\hline C & 9.871745 & 7.229196 & 0.0000 & & & \\
KM & $-1.07 \mathrm{E}-06$ & -2.616457 & 0.0181 & 6.845849 & 0.018054 & 0.287088 \\
\hline
\end{tabular}

Sumber: Data diolah, 2018

Berdasarkan tabel 6, maka dapat di peroleh persamaan regresi sebagai berikut:

INF $=9.871745+-1.07 \mathrm{E}-06 \mathrm{KM}$

Persamaan regresi linier tersebut dapat di interpretasikan sebagai berikut:

Nilai konstanta dari estimasi mempunyai koefisien regresi sebesar 9.871745 memberikan arti bahwa jika konsumsi masyarakat Indonesia adalah 0 atau tidak berubah, maka inflasi Indonesia akan mengalami peningkatan sebesar $9.871745 \%$. Variabel konsumsi masyarakat Indonesia mempunyai koefisien regresi sebesar -1.07E06, hal ini menunjukkan yang berarti setiap kenaikan konsumsi masyarakat sebesar 1 miliyar rupiah maka akan meningkatkan inflasi Indonesia sebesar -1.07E-06\%. 
Tabel 7. Hasil koefisien regresi dari sisi penawaran

\begin{tabular}{cccrcrl}
\hline Variabel & Coefisien & t-hitung & Prob t-hit & F-hitung & Prop F-hit & R $^{2}$ \\
\hline C & -32.28109 & -3.070099 & 0.0078 & & & \\
ER & 0.000641 & 1.648869 & 0.1200 & 9.142303 & 0.001104 & 0.646451 \\
TBP & 1.983381 & 4.710801 & 0.0003 & & & \\
HMD & 0.089106 & 2.755598 & 0.0147 & & & \\
\hline
\end{tabular}

Sumber: Data diolah, 2018

Berdasarkan Tabel 7, maka dapat di peroleh persamaan regresi sebagai berikut:

$$
\text { INF }=-32.28109+0.000641 \mathrm{ER}+1.983381 \mathrm{TBP}+\mathbf{0 . 0 8 9 1 0 6 H M D}
$$

Persamaan regresi linier tersebut dapat di interpretasikan sebagai berikut:

Nilai konstanta dari estimasi mempunyai koefisien regresi sebesar -32.28109 memberikan arti bahwa jika kurs, tingkat bunga pinjaman dan harga minyak dunia adalah 0 atau tidak berubah, maka inflasi Indonesia akan mengalami peningkatan sebesar $-32.28109 \%$.

Variabel kurs di Indonesia mempunyai koefisien regresi sebesar 0.000641, hal ini menunjukkan yang berarti setiap kenaikan kurs sebesar 1 rupiah maka akan meningkatkan inflasi Indonesia $0.000641 \%$.

Variabel tingkat bunga pinjaman mempunyai koefisien regresi sebesar 1.983381, hal ini menunjukkan yang berarti setiap kenaikan tingkat bunga pinjaman sebesar 1 miliyar rupiah maka akan meningkatkan inflasi Indonesia sebesar $1.983381 \%$.

Variabel harga minyak dunia mempunyai koefisien regresi sebesar 0.089106, hal ini menunjukkan yang berarti setiap kenaikan harga minyak dunia sebesar 1 barel maka akan meningkatkan inflasi sebesar $0.089106 \%$.

\section{Pengujian asumsi klasik}

\section{Uji multikolinearitas}

Uji multikolinearitas adalah untuk mengetahui ada tidaknya hubungan linier yang sempurna atau pasti diantara beberapa atau semua variabel yang menjelaskan dari model regresi. Untuk mengetahui indikasi gejala multikolinearitas dapat diketahui dari nilai tolerance dan Variance Influence Factor (VIF). Nilai cuttof yang umum digunakan adalah nilai tolerance diatas 0.10 atau nilai VIF dibawah 10.

Tabel 8. Hasil uji multikolinearitas dari sisi penawaran

\begin{tabular}{cccc}
\hline Variable & $\begin{array}{c}\text { Coefficient } \\
\text { Variance }\end{array}$ & $\begin{array}{c}\text { Uncentered } \\
\text { VIF }\end{array}$ & $\begin{array}{c}\text { Centered } \\
\text { VIF }\end{array}$ \\
\hline C & 110.5584 & 338.7992 & NA \\
ER & $1.51 \mathrm{E}-07$ & 53.75962 & 1.868913 \\
TBP & 0.177265 & 102.6362 & 2.869240 \\
HMD & 0.001046 & 14.63811 & 2.017024 \\
\hline
\end{tabular}

Sumber: Data diolah, 2018

Dari hasil uji multikolinearitas dapat diketahui bahwa model tersebut lolos dari masalah miltikolinearitas, dapat dilihat dari VIF yaitu kurs, tingkat bunga pinjaman dan harga minyak dunia lebih kecil dari 10. Dimana nilai VIF kurs sebesar 1.868913, tingkat bunga pinjaman sebesar 2.869240 dan harga minyak dunia sebesar 2.017024 . Dengan demikian, dapat disimpulkan bahwa model tersebut lulus dari masalah multikolinearitas atau tidak mengandung korelasi antara variabel independen. 


\section{Uji heterokedastisitas}

Uji heterokedastisitas terjadi saat residual dan nilai prediksi mempunyai pola hubungan. Pola hubungan ini tidak hanya sebatas hubungan linier tetapi juga berbeda. Metode uji heterokedastisitas yang digunakan adalah Breusch-Pagan-Godfrey. Apabila nilai prob F-hitung $>\alpha=10 \%$ maka tidak terindikasi adanya gejala heterokedastisitas. Berikut ini model Heterokedastisitas dapat dilihat pada tabel berikut:

Tabel 9. Hasil regresi heterokedastisitas dari sisi penawaran

\begin{tabular}{llll}
\hline F-statistic & 0.367271 & Prob. F(3,15) & 0.7777 \\
Obs*R-squared & 1.300129 & Prob. Chi-Square(3) & 0.7291 \\
Scaled explained SS & 1.874657 & Prob. Chi-Square(3 & 0.5988 \\
\hline
\end{tabular}

Sumber: Data diolah, 2018

Pada Tabel 9 menunjukkan hasil uji heterokedastisitas dapat diketahui bahwa model tersebut lolos dari masalah heterokedastisitas dengan melihat nilai porb F-hitung sebesar 0.7291, oleh karena itu nilai p-value $0.7291>\alpha=10 \%$ maka $\mathrm{H}_{0}$ diterima sehingga dapat disimpulkan model regresi tidak terindikasi adanya gejala heterokedastisitas.

\section{Uji autokorelasi}

Untuk mengetahui indikasi gejala autukorelasi digunakan metode Breuch-Godfrey atau disebut sebagai uji Langrange Multiplier, yang mana jika probabilita $>\alpha=1 \%, \alpha=$ $5 \%, \alpha=10 \%$ maka tidak terindikasi gejala autokorelasi. Berikut ini model dapat dilihat pada tabel berikut.

Tabel 10. Hasil regresi autokorelasi dari sisi penawaran

\begin{tabular}{llll} 
F-statistic & 1.703252 & Prob. F(2,13) & 0.2203 \\
Obs*R-squared & 3.944995 & Prob. Chi-Square(2) & 0.1391 \\
\hline
\end{tabular}

Sumber: Data diolah, 2018

Pada Table 10 menunjukkan hasil uji autokorelasi dapat diketahui bawha model tersebut lolos dari masalah autokorelasi, dengan melihat bawha nilai Prop $\mathrm{F}(2,13)$ sebesar 0.2203 . oleh karena itu nilai p-value $0.2203>\alpha=5 \%$ sehingga $\mathrm{H}_{0}$ diterima sehingga dapat disimpulkan maka regresi tidak terindikasi adanya gejala autokorelasi.

\section{Pengujian hipotesa}

\section{Uji signifikansi statistik secara stimulan (Uji F)}

Uji F statistik dilakukan untuk melihat pengaruh variabel independen yaitu kurs, tingkat bunga pinjaman, harga minyak dunia, konsumsi masyarakat Indonesia secara simultan atau secara bersama-sama terhadap variabel dependen yaitu inflasi Indonesia. Hasil regresi linier sederhana dan regresi linier berganda yang dilihat dari sisi permintaan dan penawaran untuk menguji statistik $\mathrm{F}$ yang terdapat pada table yaitu hasil regresi diketahui atau diperoleh dengan membandingkan nilai $\mathrm{F}$ statistik dari sisi permintaan dengan probabilitas sebesar 0.015307 atau lebih kecil dari $\alpha=0,05$, sedangkan dari sisi penawaran sebesar 0.001104 atau lebih kecil dari $\alpha=0,05$. Artinya $\mathrm{H}_{0}$ ditolak dan $\mathrm{H}_{\mathrm{a}}$ diterima. Hal ini dapat diartikan bahwa variabel bebas kurs, tingkat bunga pinjaman, harga minyak dunia, konsumsi masyarakat dan jumlah uang beredar secara bersama-sama (simultan) berpengaruh signifikan terhadap variabel terikat inflasi di Indonesia selama periode 2000-2018. 


\section{Uji signifikansi statistik secara parsial (Uji-t)}

Uji t digunakan untuk menganalisis hipotesis secara parsial (individual) guna mengetahui seberapa signifikan atau tidak signifikannya pengaruh masing-masing variabel. Pengujian ini digunakan dengan membandingkan nilai probabilitas dengan besaran signifikan pada taraf $\alpha=1 \%, \alpha=5 \%$ atau $\alpha=10 \%$. Dengan kriteria pengujian jika nilai probabilitas dari salah satu variabel independen melebihi $\alpha=10 \%$, maka pengaruh variabel independen tidak signifikan sehingga $\mathrm{H}_{0}$ diterima, yang artinya bahwa variabel independen tidak berpengaruh secara parsial terhadap variabel dependen. Sebaliknya, apabila nilai probabilitas dari salah satu variabel independen dengan memiliki nilai besaran signifikansi pada taraf $\alpha=1 \%, \alpha=5 \%$ atau $\alpha=10 \%$ maka pengaruh variabel independen signifikan, sehingga $\mathrm{H}_{\mathrm{a}}$ diterima yang artinya bahwa variabel independen memiliki pengaruh secara parsial terhadap variabel dependen.

\section{Uji terhadap parameter kurs}

Dari hasil perhitungan diperoleh nilai probabilitas untuk variabel independen kurs sebesar 0,1200 dan tidak signifikan pada taraf $\alpha=1 \%, \alpha=5 \%$ bahkan $\alpha=10 \%$ sehingga $\mathrm{H}_{0}$ diterima. Maka secara parsial kurs tidak berpengaruh signifikan terhadap inflasi Indonesia periode 2000-2018. Artinya adalah kurs tidak signifikan terhadap inflasi karena ada faktor lain yang mempengaruhi inflasi.

\section{Uji terhadap parameter tingkat bunga pinjam}

Dari hasil perhitungan diperoleh nilai probabilitas untuk variabel independen tingkat bunga pinjaman sebesar 0,0003 dan signifikan pada taraf $\alpha=1 \%, \alpha=5 \%, \alpha=$ $10 \% \mathrm{H}_{0}$ ditolak. Maka secara parsial tingkat bunga pinjaman berpengaruh signifikan terhadap inflasi Indonesia periode 2000-2018.

\section{Uji terhadap parameter harga minyak dunia}

Dari hasil perhitungan diperoleh nilai probabilitas untuk variabel independen harga minyak dunia sebesar 0,0147 dan signifikan pada taraf $\alpha=1 \%, \alpha=5 \%, \alpha=10 \%$ $\mathrm{H}_{0}$ ditolak. Maka secara parsil harga minyak dunia berpengaruh signifikan terhadap inflasi Indonesia periode 2000-2018.

\section{Uji terhadap parameter konsumsi masyarakat}

Dari hasil perhitungan diperoleh nilai probabilitas untuk variabel independen konsumsi masyarakat sebesar 0,0181 dan signifikan pada taraf $\alpha=1 \%, \alpha=5 \%, \alpha=$ $10 \% \mathrm{H}_{0}$ diterima. Maka secara parsial konsumsi masyarakat berpengaruh signifikan terhadap inflasi Indonesia periode 2000-2018.

\section{Koefisien determinasi $\left(\mathbf{R}^{2}\right)$}

Koefisien determinasi dimaksudkan untuk mengetahui seberapa besar kontribusi setiap variabel independen terhadap variabel dependen secara bersama-sama. Apabila nilai koefisien determinasi $\left(\mathrm{R}^{2}\right)$ semakin mendekati satu, maka persamaan regresi yang dihasilkan baik untuk mengestimasi nilai variabel dependen. Pada hasil perhitungan dapat dilihat bahwa nilai koefisien determinasi dari sisi permintaan $\left(\mathrm{R}^{2}\right)$ sebesar 0.2870 persen sedangkan nilai koefisien determinasi dari sisi penawaran $\left(R^{2}\right)$ sebesar 0.6464 , maka demikian nilai koefisien determinasi tersebut mempunyai arti bahwa pengaruh seluruh variabel independen yaitu kurs, tingkat bunga pinjaman, harga minyak dunia konsumsi masyarakat Indonesia terhadap variabel dependen yaitu inflasi di Indonesia adalah sebesar 28,70 persen dan sebesar 64,64 persen. Selebihnya 71,03 persen dan 35.36 persen dapat dijelaskan oleh variabel lain diluar model. 


\section{KESIMPULAN DAN SARAN}

\section{Kesimpulan}

Hasil analisis baik secara deskriptif maupun kuantitatif dengan menggunakan model regresi linier berganda dilihat dari sisi permintaan dan penawaran dibantu dengan software Eviews 9.0 maka dapat diambil kesimpulan sebagai berikut : Selama periode 2019-2025 trend inflasi, kurs, tingkat bunga pinjaman, harga minyak dunia,konsumsi masyarakat Indonesia dan jumlah uang beredar berfluktuasi serta memiliki kecendrungan meningkat, dengan rata-rata masing-masing variabel inflasi sebesar 2,71\%, kurs sebesar Rp. 14.143, tingkat bunga pinjaman sebesar 12,15\%, harga minyak dunia 91,67 US\$/barel, konsumsi masyarakat Indonesia sebesar 6.850.384 miliyar rupiah. Faktor-faktor yang mempengaruhi inflasi dilihat dari permintaan dan penawaran selama periode 2000-2018. Berdasarkan hasil perhitungan regresi linier berganda, variabel kurs, tingkat bunga pinjaman, harga minyak dunia konsumsi masyarakat indonesia secara bersama-sama atau simultan mempengaruhi inflasi di indonesia. Secara parsial variabel tingkat bunga pinjaman, harga minyak dunia dan konsumsi masyarakat indonesia berpengaruh positif dan signifikan terhadap inflasi di Indonesia, sedangkan variabel kurs tidak signifikan terhadap inflasi di Indonesia.

\section{Saran}

Nilai trend inflasi, kurs, tingkat bunga pinjaman, harga minyak dunia, konsumsi masyarakat di Indonesia berfluktuatif serta memiliki kecendrungan meningkat namun terkecuali untuk variabel tingkat bunga pinjaman. Maka diharapkan pengendalian inflasi melalui kebijakan moneter dengan menggunakan jumlah uang beredar sebagai instrumen moneter belum menunjukkan pengaruh yang signifikan. Faktor-faktor yang mempengaruhi inflasi di Indonesia dengan yakni variabel kurs, tingkat bunga pinjaman, harga minyak dunia, konsumsi masyarakat, ternyata memiliki pengaruh yang signifikan terhadap inflasi di Indonesia. Maka kebijakan yang diambil lebih menjaga kestabilan kurs dengan menetapkan kebijakan moneter yang di tujukan untuk mencapai dan memelihara kestabilan nilai rupiah juga pemerintah perlu melakukan upaya menaikkan pendapatan nasional sebagai salah satu faktor yang menentukan besarnya pengeluaran konsumsi masyarakat dan menciptakan pertumbuhan ekonomi yang tinggi, mengingat pengeluaran konsumsi masyarakat Indonesia sudah menjadi faktor penggerak perekonomian negara.

\section{DAFTAR PUSTAKA}

Boediono. (1990). Ekonomi moneter. Edisi ke 3. BPFE Yogyakarta

Gujarati, Damodar. (2003). Econometric.Jakarta: Erlangga

Haryadi. (2014). Ekonomi internasional (Teori dan aplikasi). Biografika: Jambi.

Krugman, P. Paul dan Obsfeld, Maurice. (2005). Ekonomi internasional: Jilid 2. PT. Indeks Kelompok Gramedia: Jakarta.

Kasmir. (2006). Manajemen perbankan. PT Raja Grafindo Persada: Jakarta

Mankiw, N. Gregory. (2007). Makroekonomi, Edisi Keenam. Fitria Liza dan Imam Nurmawan [Penterjemah]. Erlangga: Jakarta.

Mankiw, Gregory N. (2003). Teori makro ekonomi. Terjemahan. Erlangga: Jakarta

Samuelson, P. (2001). Makroekonomi. Erlangga: Jakarta.

Selvatore, Dominick. (2003). International economic. Jhon Wiley \& Sons: USA

Deliarnov. (2006). Ekonomi politik. Erlangga: Jakarta.

Yudiarti,T; Emilia,E; \& Mustika,C. (2018).Pengaruh utang luar negeri, tingkat suku bunga dan neraca transaksi berjalan terhadap nilai tukar Rupiah terhadap Dolar Amerika Serikat, e-Jurnal Perdagangan Industri dan Moneter 6 (1), 14-22 